DOI: 10.31866/2617-2674.3.2.2020.217634

UDC 621.396.7:316.334.52:303.643.2

\title{
REGIONAL RADIO STATIONS AS MEANS OF AUDIO INFORMATION TRANSMITTING
}

\author{
Serhii Honcharuk ${ }^{1 a}$, Nataliia Tsaruk ${ }^{2 a}$ \\ ${ }^{1}$ PhD in Pedagogy, Associate Professor; \\ e-mail: goncharucs@gmail.com; ORCID: 0000-0003-0878-6143 \\ ${ }^{2}$ Master's Student, Television Journalism and Acting Department; \\ e-mail: natasha.caryk@gmail.com; ORCID: 0000-0001-5011-2623 \\ ${ }^{a}$ Kyiv National University of Culture and Arts, Kyiv, Ukraine
}

Keywords:
regional;
radio broadcast;
radio station;
format;
typology;
category

For citation:

\begin{abstract}
The purpose of this research is to show the categories of regional broadcasters, their difference from the capital and to explore the problems and benefits of such stations. Research methodology. The following research methods were used in the course of the article: empirical (to study the characteristics of Ukrainian regional languages of the $21^{\text {st }}$ century); complex-analytical (for opening and formulating the conceptual apparatus of research and study of the problem); comparison (to understand how they differ or what is common in radio stations); systematization (summarizing the analyzed information in the conclusions). Scientific novelty. For the first time an analysis of typological features and characteristics of regional broadcasting was conducted, the classification of Ukrainian radio stations was described, new categories appeared in modern broadcasters. Conclusions. During the study of the features of regional radio stations as a means of transmitting audio information, the scientific works of the researchers of this phenomenon were analyzed. On the basis of these tasks, the characteristics of radio stations of the last twenty years were studied; the problem is identified and studied; the common and distinctive features of regional radio stations were analyzed and all the information processed was summarized.
\end{abstract}

Honcharuk, S. and Tsaruk, N. (2020). Regional radio stations as means of audio information transmitting. Bulletin of Kyiv National University of Culture and Arts. Series in Audiovisual Arts and Production, 3(2), pp.167-174.

\section{Problem Statement}

Radio broadcasting is a rather rare subject of discussion in society and specialized scientific conferences. After all, few people undertake such research. There is not much information that can be conveyed or researched. But if radio in Ukraine continues to develop and improve, you can take a risk and try to show its scientific side. As for regional broadcasters, very little is known about them, because most listeners of such stations are residents of small towns and villages. Therefore, 
the question arises whether there is a big difference in the comparison of regional and network broadcasting, what are the typological features and characteristics.

\section{Recent research and publications analysis}

After researching the concept of "regional radio stations" it became clear that there is no special literature, but there are books and articles that mention them. Most information has been found in the works of such authors as O. Goian, L. Bolotov, Y. Kostiuk, O. Raskatov, A. Shershel, etc. Each of them reveals the topic of radio broadcasting in an original and unique way. In both cases, the tasks are almost the same: to be original, to reveal the theme through original schemes, and to show personal creativity, while remembering the uniqueness of the work.

\section{Purpose of the article}

The purpose of the research is to show the categories of regional broadcasters, their difference from the capital and to analyze the problems and advantages of such stations.

The following tasks were set according to the goal:

- analysis of the main characteristics of the radio;

- classification of domestic stations;

- predict and explain the emergence of new categories of speech in the media.

\section{Main research material}

Radio is both a practical and a theoretical field in journalism. Its development took place in technological, programmatic, creative, political and social aspects.
Of course, many changes affected the activities of radio, but certain norms and types have been preserved to this day. An example is that the station, despite its format, continues to maintain its organizational form among most existing media. Typological characteristics of the radio and gave push to some analysis, which helped to approach the relevance of the topic.

Modern radio is a large part of the Ukrainian media space, which was created almost all of the $20^{\text {th }}$ century. The norms and rules of most regional stations are directed by the capital's broadcasters. Therefore, the format plays an important role here.

By 2020, there are more than 50 different regional broadcasters in Ukraine. Most work is in Khmelnytskyi, Lviv, Kyiv, Odesa and Ivano-Frankivsk regions.

Regional radio stations work to:

- in each small town or village there was an independent and local radio;

- the disadvantaged and pensioners had ways to listening;

- create their own relevant and interesting programs for the residents of a certain area with the participation of public figures, local authorities and residents who may be interested in something;

- Ukrainians in any part of the country had access to information;

- inform people about breaking news in the district, city or village;

- advertisers of a certain area could cooperate with the broadcaster (Charitable Fund for Social Development of Kharkiv region, 2018).

After conducting their analysis of various Ukrainian regional radio stations in order to identify the characteristics, they were classified. They are all different, but have their own characteristics and are divided 
by criteria: socially significant, creative and organizational.

The work of radio stations is connected with the life and development of society. It is created for people by people themselves. Therefore, according to the criteria of regional stations, the most important is a socially significant group, which includes owners, target audience and staff of stations, which is creative in any work.

The owner is the person who owns the property (Vlasnyk, 1998). In radio broadcasting, it is a physical or legal person who invests money in broadcasting and receives certain income. Therefore, it follows from this concept that radio stations can be state, non-state, commercial and noncommercial (Kostyuk, 2014).

According to the Law of Ukraine (1993) "On Television and Radio Broadcasting", all radio stations are divided into "... state and municipal television and radio organizations, the system of Public Television and Radio Broadcasting of Ukraine, private, public and other television and radio organizations". An example is the Zaporizhia station "Zaporizhia FM", which operates on the 103.7 MHz waves, and is owned by the State Committee for Television and Radio Broadcasting. Stateowned stations receive funds for their development from the state budget, and profits are possible through the placement of sponsorship, advertising and more.

The non-state, so-called public form includes regional stations that operate on one collective form of ownership. "Thus, a non-state radio station is, first of all, a private or public enterprise, the purpose of which is to satisfy the needs or interests of a certain target audience" (Hoian, 2004, p.18).

The creation of a commercial station is largely associated with profit. An indicator of a successful open broadcaster is market activity and popularity among listeners. That's why most of the money comes from advertising because the right sale of radio airtime to advertisers sets a pricing policy. When the employees of the station understand how to sell their format correctly, who their potential listener is, what he wants and aspires to, the indicators of sales of advertising grow, and the radio station gains momentum among competitors. Examples of successful investments in the opening and development of commercial stations are: in Lviv “FM Halychyna” - 89.7 MHz (LLC "Energy Consulting"), in Kyiv "Business Radio" - 93.8 FM (radio holding Business Radio Group), "DJ FM" - 96.8 MHz (business holding Business Radio Group), "Voice of the Capital" - 106.0 MHz (radio group “Ukrainian Media Holding”), NRJ 92.8 MHz (Ukrainian Media Holding radio group), etc.

A non-commercial radio station differs from others in that commercial activity is not the main one for them, "... although it can be considered only as ancillary and relate, for example, to terrestrial support of ethnic, social and other communities, public actions, etc." (Hoian, 2004, p.19). Their work is due to certain charitable contributions from students, patrons and government subsidies. The main orientation of such broadcasters is the audience, especially the one that helps them to exist. There are no such radio stations in Ukraine yet.

In order to analyze the target audience, a number of factors must be taken into account: age, education, place of birth and residence, marital status, aesthetic tastes, place of study or work, and musical interests. The Russian actress and radio host divides the audience of regional stations into several types: 
- the target to which the broadcast as a whole or a separate program is directed; - admissible, as a result of switching on any station everyone can become a listener, even if it was accidental;

- interested, which unites those who invest in a radio station and participate in the work of the broadcaster;

- accidental, it includes people who accidentally turned on the station and stayed on its wave (Raskatova, 2009).

The key figure for the work of stations is the selection of a creative team. Financial turnover depends on the owner, economic indicators and success in the advertising market in the region, the popularity of the station among listeners and other factors. Therefore, the operation of the radio requires at least three departments:

- managerial - radio station management;

- journalistic or creative - presenters, DJs, editors;

- technical - cameramen, directors, etc. (Kiit, 2001, p.36).

Such a division does not always occur at regional stations, their staff is small, forcing some employees to combine several positions at once. At the same time, work in the regions is always balanced and professional.

The typology of Ukrainian radio broadcasting has a certain range of broadcasting and territory. "According to the method of signal propagation, stations are wired, terrestrial, satellite and Internet radio stations" (Hoian, 2004, p.20). In Ukraine, the first two groups among regional stations are used. The wired ones include Zaporozhia "Radio Three”, "Radio Zaporizhia", Luhansk regional radio, Lviv "Hromadske Slovo", "Western capital”, "Lviv radio", metropolitan "Voice of Kyiv", "Voice of Kyiv", "Maidan Studio".
Most commercial radios carry their product to the masses through waves and special transceivers. It is thanks to them that speech is divided into ranges: long waves (DC), medium waves (CX), short waves (CX) and ultrashort waves (Kostiuk, 2014, p.33).

There are both local and network stations in Ukraine. The latter group is also called creative due to the territorial factor because it includes the format and type of work of the station. It is network radio stations that set the fashion for the work of leading programs, authors and editors. Local stations are those that operate in one regional market. For example, "Zaporizhia FM", "Pulse FM". Network stations can broadcast in several local or regional media markets at once. They are the main among the number of frequencies of various bands in Ukraine. Examples of winning broadcasters are Business Radio, Ukrainian Media Holding, and Lviv Radio.

Radio formats are divided into conversational and musical. In general, the concept of format - one of the important styles in the development of the station, which is created to meet the interests of the audience (Format radiomovlennia, 2009). These are very clear requirements for the quality of information on the air, which vary the balance between news and entertainment content, music, advertising. According to Olga Raskatova (2009), the format includes "... competently built structure of speech programming, correctly chosen musical strategy and manner of conducting programs, the presence of appropriate ethical and aesthetic standards of the team."

Elements of the format follow from the correctly constructed structure. These include news, music, talk content, images and voices of presenters, advertising and podcasts. 
Doctor of Philology Oles Hoian (2004, pp.21-22) classifies radio stations into:

- conversational;

- musical;

- conversational and musical;

- musical and conversational.

Their name depends largely on the percentage of music content and information on the radio station (Hoian, 2004; Shershel, 2002).

Broadcasts of regional stations also have their own division: translators and repeaters. But even in this variation of a station, it is important to be guided by the Law of Ukraine (1993) "On Television and Radio Broadcasting", which states that "... at least $50 \%$ of domestic production must be broadcast".

\section{Conclusions}

During the writing of the article and research on the topic, an analysis of the works of many domestic and foreign scientists who studied the typology of regional stations in different parts of the world (Hoian, 2004; Bolotova, 2005; Bubukin, 1995; Sukhareva, 1999). Thanks to various sources, the criteria of type-forming groups of radio have been found, which include the form of ownership, signal coverage range, means of station development, type, format, methods and techniques of live broadcasts.

It is worth agreeing with the views of many scientists who point out that radio will soon become uninteresting to anyone and the first among the audio-visual broadcasting will disappear from the lives of listeners. But it continues to provoke and creates a search for new areas of development and activity. Technology in the $21^{\text {st }}$ century does not stand still, but innovation becomes not just a buzzword in the lexicon of Ukrainians, but part of the improvement of radio. Besides, new mechanisms and typological categories of stations appear. An example is Internet radio, which already has a huge development abroad and listeners. In Ukraine, it is just beginning to take small steps and is waiting for the good development of the Internet, because everything depends only on the transmission of the bottom.

Such stations have complete freedom and autonomy. They do not depend on quotas and laws, and the owner or editor chooses what will sound on his Internet waves, and in what language. Most regional stations are already creating online eavesdropping on their websites, as this is becoming a popular and important part of development in the modern world. Network stations even create special applications for smartphones so that the listener is not tied to a computer and can turn on your favourite radio station anywhere with the Internet.

The study, conducted for this article, in no way covers the typological problems and characteristics of modern Ukrainian regional radio stations. But at the same time, it proves that such broadcasters are needed and interesting to their listeners, even if there are not so many of them. The issue of regional stations is still not fully resolved. Therefore, this topic is interesting for further study and requires a lot of work with scientific, theoretical and practical material, especially foreign.

\section{REFERENCES}

Bolotova, L.D., 2005. Osobennosti sovremennogo [Features of modern]. In: Ja.N. Zasurskogo, ed. Teleradiojefir: Istorija i sovremennost' [V and radio: History and modernity]. Moscow: Aspekt Press. 
Bubukin, A., 1995. Interaktivnost' na radio: tol'ko pljusy! [Interactivity on the radio: only the pros!]. [online] Available at: <http//gyzei.com/radio/journal/article/intrp.php> [Accessed 16 January 2020].

Format radiomovlennia, 2009. Vikipediia - vilna entsyklopediia [Vikipediya - Vilna encyclopedia]. [online] Available at: <https://uk.wikipedia.org/wiki/Format_radiomovlennya> [Accessed 16 January 2020].

Hoian, O.la., 2004. Osnovy radiozhurnalistyky $i$ radiomenedzhmentu [Fundamentals of radio journalism and radio management]. Kyiv: Veselka.

Hoian, O.la., 2005. Komertsiyhe radiomovlennia: zhurnalistyka $i$ pidpryiemnytstvo $v$ radioefiri [Commercial broadcasting: journalism and entrepreneurship on the radio]. Kyiv: Naukova dumka.

Kiit, M., 2001. Radiostantciia [Radio station]. Translation: A.I. Fililekina. Moscow: Mir.

Kostiuk, Yu.V., 2014. Typolohichni kharakterystyky suchasnoho rehionalnoho radiomovlennia [Typological characteristics of modern regional radio broadcasting]. Naukovi zapysky Instytutu zhurnalistyky, [online] 56, c.30-34. Available at: <http://www.irbisnbuv.gov.ua/cgibin/irbis_nbuv/ cgiirbis_64.exe?I21DBN=LINK\&P21DBN=UJRN\&Z21ID =\&S21REF=10\&S21CNR=20\&S21STN=1\& S21FMT=ASP_meta\&C21COM=S\&2_S21P03=FILA=\&2_S21STR=Nzizh_2014_56_7> [Accessed 20 January 2020].

Raskatova, O., 2009. Tipologicheskaia kharakteristika sovremennogo radioveshchaniia [Typological characteristics of modern radio broadcasting]. [online] Available at: <http://kgujournalist.ucoz.ru/publ/4-1-0-40> [Accessed 16 January 2020]. Shershel, A., 2002. Radiozhurnalistika [Radio journalism]. 2nd ed. Moscow: Vysshaia shkola.

Stvorennia merezhi rehionalnykh FM-radiostantsii [Creating a network of regional FM radio stations], 2018. Blahodiinyi fond sotsialnoho rozvytku Kharkivskoi oblasti. [online] Available at: <http://rozvytok.kharkov.ua/ua/> [Accessed 22 January 2020].

Sukhareva, V.A., 1999. Radio v Internete [Radio on the Internet]. Sreda, 10.

Vlasnyk, 1998. Vikipediia - vilna entsyklopediia [Wikipedia is a free encyclopedia]. [online] Available at: <https://uk.wikipedia.org/wiki/Vlasnyk> [Accessed 16 January 2020].

Zakony Ukrainy, 1993. Pro telebachennia i radiomovlennia (№3759-XII) [On television and radio broadcasting (№3759-XII)]. Verkhovna Rada Ukrainy. [online] Available at: <http://zakon4.rada. gov.ua/laws/show/3759-12> [Accessed 20 January 2020]. 


\title{
РЕГІОНАЛЬНІ РАДІОСТАНЦІї ЯК ЗАСІБ ПЕРЕДАЧІ АУДІОІНФОРМАЦІЇ
}

\author{
Сергій Гончарук ${ }^{1 a}$, Наталія Царук²a \\ ${ }^{1}$ кандидат педагогічних наук, доцент; \\ e-mail: goncharucs@gmail.com; ORCID: 0000-0003-0878-6143 \\ ${ }^{2}$ магістрант кафедри тележурналістики та майстерності актора; \\ e-mail: natasha.caryk@gmail.com; ORCID: 0000-0001-5011-2623

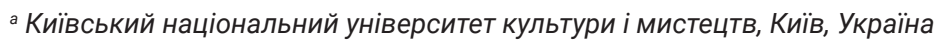

\begin{abstract}
Анотація
Мета дослідження - показати категорії регіональних мовників, їх різницю від столичних та проаналізувати проблеми та плюси таких станцій. Методологія дослідження. Під час роботи зі статтею використовувалися такі методи: емпіричні (для вивчення характеристик українських регіональних мовників XXI століття); комплексно-аналітичні (для розкриття та формулювання понятійного апарату дослідження та вивчення проблеми); зіставлення (задля розуміння чим відрізняються або що спільного у радіостанціях); систематизації (узагальнення проаналізованої інформації у висновках). Наукова новизна. Вперше було проведено аналіз типологічних особливостей та характеристик регіонального радіомовлення, описано класифікацію українських радіостанцій, досліджено появу нових категорій в сучасних мовників. Висновки. Під час дослідження особливостей регіональних радіостанцій як засобу передачі аудіоінформації було проаналізовано наукові праці дослідників даного явища. На основі поставлених завдань було вивчено характеристики радіостанцій останнього двадцятиріччя; розкрито та вивчено проблему; проаналізовано спільні та відмінні риси регіональних радіостанцій та узагальнено всю оброблену інформацію.
\end{abstract}

Ключові слова: регіональний; радіомовлення; радіостанція; формат; типологія; категорія 


\title{
РЕГИОНАЛЬНЫЕ РАДИОСТАНЦИИ КАК СРЕДСТВО ПЕРЕДАЧИ АУДИОИНФОРМАЦИИ
}

\author{
Сергей Гончарук ${ }^{1 a}$, Наталия Царук²a \\ ${ }^{1}$ кандидат педагогических наук, доцент; \\ e mail: goncharucs@gmail.com; ORCID: 0000-0003-0878-6143 \\ ${ }^{2}$ магистрант кафедры тележурналистики и мастерства актера; \\ e-mail: natasha.caryk@gmail.com; ORCID: 0000-0001-5011-2623 \\ а Киевский национальный университет культуры и искусств, Киев, Украина
}

\begin{abstract}
Аннотация
Цель исследования - показать категории региональных вещателей, их разницу от столичных и проанализировать проблемы и плюсы таких станций. Методология исследования. При работе со статьей использовались следующие методы: эмпирические (для изучения характеристик украинских региональных вещателей XXI века); комплексно-аналитические (для раскрытия и формулировки понятийного аппарата исследования и изучения проблемы); сопоставления (для понимания чем отличаются или что общего у радиостанций); систематизации (обобщение проанализированной информации в выводах). Научная новизна. Впервые был проведен анализ типологических особенностей и характеристик регионального радиовещания, описано классификацию украинский радиостанций, исследовано появление новых категорий в современных вещателей. Выводы. В ходе исследования особенностей региональных радиостанций как средства передачи аудиоинформации были проанализированы научные труды исследователей данного явления. На основе поставленных задач были изучены характеристики радиостанций последнего двадцатилетия; раскрыто и изучено проблему; проанализированы общие и отличительные черты региональных радиостанций и обобщено всю обработанную информацию.
\end{abstract}

Ключевые слова: региональный; радиовещание; радиостанция; формат; типология; категория 